\title{
Hızlı progresif görme kaybı ile giden ve puls steroid tedavisinden yararlanan bir idiyopatik intrakraniyal hipertansiyon olgusu
}

\author{
Zahide Mail Gürkan ${ }^{1}$, Ülgen Yalaz Tekan², Ayşe Destina Yalçın ${ }^{3}$, Lale Gündoğdu Çelebi ${ }^{4}$, Gülay Kenangil ${ }^{5}$, \\ Zeynep Tanriverdi ${ }^{4}$, Hulki Forta ${ }^{4}$
}

\begin{abstract}
ÖZET:
Hızlı progresif görme kaybı ile giden ve puls steroid tedavisinden yararlanan bir idiyopatik intrakraniyal hipertansiyon olgusu

Bu çalışmada 28 yaşında hızlı yerleşen görme kaybı ile başvuran bir idyopatik intrakraniyal hipertansiyon olgusu sunulmuştur. Etiyolojik faktör olarak polikistik over hastalığı, kısa süreli oral kontraseptif kullanımı ve demir eksikliği saptandı. Hastaya oral asetozolamid tedavisinin yanında 3 gün süre ile IV $1 \mathrm{gr} / \mathrm{gün}$ metilpednizolon tedavisi verildi. Ayrıca hastaya boşaltıcı lomber ponksiyonlar ve lumboperitoneal şant uygulandı. İdiyopatik intrakraniyal hipertansiyonun seyri sırasında nadir de olsa görme kaybı hızla gelişebilir. Bu olguda yüksek doz intravenöz kortikosteroid tedavisi zaman kazanmak ve görmenin düzelmesi açısından yararlı olabilmektedir.

Anahtar kelimeler: İdyopatik intrakraniyal hipertansiyon, görme kaybı, intravenöz kortikosteroid tedavisi

\section{ABSTRACT:}

A case of idiopatic intracranial hypertension with rapidly progressive vision loss and that benefits from pulse steroid therapy

In this report, a 28-year-old patient who had idiopathic intracranial hypertension with rapidly progressive visual loss was reported. Etiological factors were polycystic ovarian disease, short-term oral contraceptive use and iron deficiency. She was administrated oral acetozolamid and metilprednizolon IV 1g/day. In addition to drug therapy, the patient underwent repeat lumbar punctures and lumboperitoneal shunt. In idiopathic intracranial hypertension, it is very rare but loss of vision may rapidly develop. In this case, high-dose intravenous corticosteroid therapy might be a god option in terms of save time to improve vision.
\end{abstract}

Key words: Idiopathic intracranial hypertension, visual loss, intravenous corticosteroid therapy

Ş.E.E.A.H. Tıp Bülteni 2013;47(2):91-94

\author{
'Medivia Hospital, İstanbul-Türkiye \\ ${ }^{2}$ Van Bölge Eğitim ve Araştırma Hastanesi, \\ Van-Türkiye \\ ${ }^{3}$ Ümraniye Eğitim ve Araştırma Hastanesi, \\ İstanbul-Türkiye \\ ${ }^{4}$ Şişli Etfal Eğitim ve Araştırma Hastanesi, \\ ìstanbul-Türkiye \\ ${ }^{5}$ Erenköy Ruh ve Sinir Hastalıkları Hastanesi \\ ìstanbul-Türkiye
}

Yazışma Adresi / Address reprint requests to: Dr. Zahide Mail Gürkan, Medivia Hospital, İstanbul-Türkiye

Telefon / Phone: +90-532-596-9852

E-posta / E-mail:

zahidail@hotmail.com

Geliş tarihi / Date of receipt:

15 Ağustos 2012 / August 15, 2012

Kabul tarihi / Date of acceptance: 10 Aralık 2012 / December 10, 2012

\section{Giriş̧}

Idyopatik intrakraniyal hipertansiyon (iiH) hidrosefali ve yer kaplayan lezyon olmadan, normal beyin omurilik sıvısı içeriği ile beraber intrakraniyal basınç artısıı sendromu olarak tanımlanan bir durumdur. Illk olarak Quincke tarafından, 1893 yılında beyin tümörü olmaksızın intrakraniyal basınç artışı saptanan hastalarda seröz menenjit olarak tanımlanmıştır. Patogenezle ilgili olarak parankimal ödem, artmış emilimi gibi tam kanıtlanamamış durumların yanında esas olarak idyopatik ifadesi artmış intrakraniyal basınca neden olacak diğer ilintili durumların (Tablo 1) bulunamamasını ifade eder.

Tanısal özellikler ilk olarak 1937'de Dandy tarafından yayınlanmış, daha sonra Smith tarafından 1985'de ve Freidman tarafından 2002'de Modifiye Dandy Kriterleri (Tablo 2) olarak formüle edilmiştir.

iiH 20/100 000'den fazla olarak ve tipik olarak doğurganlık çağındaki kadınlarda bildirilmiştir. Görsel bozukluklar geniş bir yelpazede ele alınır ve benzer karakterdedir. Görmede bulanıklaşma veya geçici görme kayıplarından, görme alanı kayıplarına kadar çeşitlilik gösterebilir. Görme kaybı fulminan 
Tablo 1: iiH ile ilintili durumlar (1)

* Endokrin ve metabolik bozuklar *Obezite ve menstrüel düzensizlikler

*Gebelik ve postpartum

*Menarş

*Kadın seks hormonları

*Addison

*Adrenal steroid geri çekilmesi

*Hiperadrenalizm

*Akromegali

*Hipoparatiroidizm

* Intrakraniyal venöz sinüs trombozu * Mastoidit ve lateral sinüs trombozu

*Kafa travması sonrası

*Gebelik ve postpartum

* Oral progestasyonel ilaçlar

*Marantik sinüs trombozu

*Kriyofibrinojemi

*Primer (idyopatik) sinüs trombozu
* Ilaçlar ve toksinler

*Vitamin A, Retinoik asit, Tetrasiklin, Nalidiksik asit,

Klordekon, Danazol, Amiodoran hidroklorid,

Lityum Karbonat, Nitrofurantoin

* Hematolojik ve konnektif doku bozuklukları

* Demir eksikliği anemisi

*Enfeksiyöz mononükleoz

*Lupus eritematozis

* Yüksek BOS protein içeriği

*Omurilik tümörleri

*Polinevrit

* Çeşitli

*Meningismus- sistemik bakteriyel veya viral enfeksiyonlar ile

*Empty sella sendromu

*Familyal sendromlar

*Sydenham koresi

*Süt çocukluğunda hızıı büyüme

*idyopatik durumlar

Tablo 2: Modifiye Dandy Kriterleri (2)

\section{MODIFIYE DANDY KRITERLERI}

1. Intrakraniyal basınç artışının semptom ve bulgularının olması- baş ağrısı, bulantı, kusma, gelip geçici görme bulanıklığı, papil ödem, altıncı sinir parezisi-

2. Artmış intrakraniyal basıncın gösterilmesi (BOS basıncı > $250 \mathrm{~mm} \mathrm{su}$ )

3. Beyin omurilik sıvısı incelemesinde sitolojik ve biyokimyasal değerlerin normal olması

4. Beyin MR' ında hidrosefali, yer kaplayan- yapısal- vasküler lezyonlara ait bulgu ya da serebral venöz tromboz düşündürecek bulgu olmaması

5. Intrakraniyal hipertansiyon yapan başka nedenlerin bulunmaması

Tablo 3: Fulminan İdyopatik İntrakraniyal Hipertansiyon (3)

*intrakraniyal hipertansiyon semptom ve bulguları akut başlar.

*Başlangıç semptomları ile ağır vizyon kaybı arasında geçen süre 4 haftadan kısadır.

*Vizyon kaybının hızla kötüleşmesi bir iki gün içinde olur.

bir seyir gösterebilir ve \%5 ile \%30 arasında görme kayıpları, progresif bir bozulmayla kalıcı olabilir (4). Bu durum Fulminan İdyopatik İntrakraniyal Hipertansiyon (Tablo 3) olarak tanımlanabilir. iiH olgularının tedavisinde kilo kaybı ve pek çok medikal tedavi seçeneklerinin yanında cerrahi tedaviler kimi zaman gerekmektedir. Özellikle vizyon kaybının hızlı ilerlediği fulminan olgularda acil cerrahi müdahaleler prognoz açısından anlamlıdır. Bunlarda cerrahi girişim ile BOS basıncını hızla düşürmek esastır. Steroi- din bu hastalarda kullanımında dikkatli olmak gerekmektedir. Uzun kullanımlarda pek çok etkisi ile hastalığı kötüleştireceği bilinmektedir. Ancak kısa süreli kullanımlar özellikle cerrahi girişim bekleyen fulminan seyirli hastalarda, zaman kazandırıcı ve görme kaybının geri dönüşümü açısından faydalı olduğu gösterilmiştir $(3,5)$.

Biz bu çalışmada hızlı ilerleyen görme kaybı gözlenen bir hastada tedavi yaklaşımını incelemeyi amaçladık. 


\section{OLGU SUNUMU}

28 yaşında kadın hasta iki ay önce başlayan, giderek şiddetlenen baş ağrısı ve yaklaşık bir hafta öncesinde gelişen iki gün içinde hızla ilerleyen tama yakın görme kaybı yakınmaları ile başvurdu. Obezitesi olan hastanın polikistik over sendromu ve hipermenoresi, yaklaşık bir ay öncesinde ise bir ay süre ile oral kontraseptif kullanımı mevcuttu. Hastanın göz dibi incelemesinde bilateral papil ödemi saptandı (Şekil 1). Her iki gözde de vizyonlar ışık hissi seviyesinde idi. Bunun dışındaki nörolojik muayenesinde özellik saptanmadı. Kranial bilgisayralı tomografi, manyetik rezonans görüntüleme (MR) ve $M R$ venografi incelemeleri normaldi (Şekil 2). Hastada intrakraniyal basınç artışı düşünülerek lomber ponksiyon yapıldı. Açılış basıncı 670 mm su olarak ölçüldü.


Şekil 1: Göz dibi fotoğrafları. Bilateral papil ödem
Beyin omurilik sıvısı incelemesinde kimyasal değerler ve mikroskobik incelemede özellik saptanmadı.

Hastanın laboratuar incelemelerinde demir eksikliği anemisi mevcuttu. Hemoglobin değeri 7,7 gr/dl, hematokrit \%27,7, MCV 49,1 fL, MCH 13,7 pg, MCHC 27,8 gr/dl, demir 14 ug/dl, total demir bağlama kapasitesi 405,00 ug/dl idi. Bunun dışındaki diğer tetkikleri normal düzeylerde idi. Demir eksikliği, polikistik over sendromu ve kısa süreli de olsa oral kontraseptif kullanımı olan hastada intrakraniyal basınç artışı ile ilintili durumlar olarak saptandı. Hastanın demir eksikliği önce 10 gün süre ile intravenöz ve sonra oral olmak üzere demir preparatları ile tedavi edildi. Asetezolamid 750 mg/gün başlandı. Görme kaybının fulminan bir seyir izlediği düşünüldü ve hastaya 3 gün süre ile intravenöz 1 gr metilprednizolon tedavisi verildi. Steroid tedavisinin son gününde vizyonda düzelme başladı ve bu düzelme devam etti. Hastaya ayrıca boşaltıcı lomber ponksiyon, birincisi steroid tedavisinden önce, ikincisi ise sonra olmak üzere iki kez uygulandı. Hasta cerrahiye hazırlandı ve birinci haftanın sonunda lumboperitoneal şant işlemi yapıldı. Hastanın görmesinde belirgin düzelme kaydedildi.

\section{SONUÇ}

Patogenezi açıklanamamış bir durum olan iiH pek çok durumla ilişkilendirilmiş bir grup hastalıktır. Bireysel farklılıkları olan, tedavi seçenekleri belirli ve semptoma yönelik olan bu hastalık grubunda temel hedef geri dönüşümsüz olabilecek optik disk hasarını önlemektir.

Birçok yayında iï hastalarındaki görme kaybından bahsedilmişse de esas olarak bu hastalarda görme keskinliği geç etkilenir. Sinsi ilerleyen bir görme kaybı vardır ve bunu saptamak için çeşitli testlere başvurmak gerekir. Ancak hızlı ilerleyen görme kayıpları da literatürde bildirilmiştir. Bunun sebebinin ise ani kafa içi basınç artışına bağlı olarak aksoplazmik staz ve optik sinir iskemisi olduğu, Thambisetty ve arkadaşlarının yayınladıkları yazıda bildirilmiştir (3). 483 iiH olgusunun 14'ünde $(\% 2,9)$ hızlı ilerleyen vizyon kaybı saptanmış olup, bunlar arasında görme kaybı için kötü prognostik faktörlerden olan demir eksikliği anemisi bir hastada, sistemik 

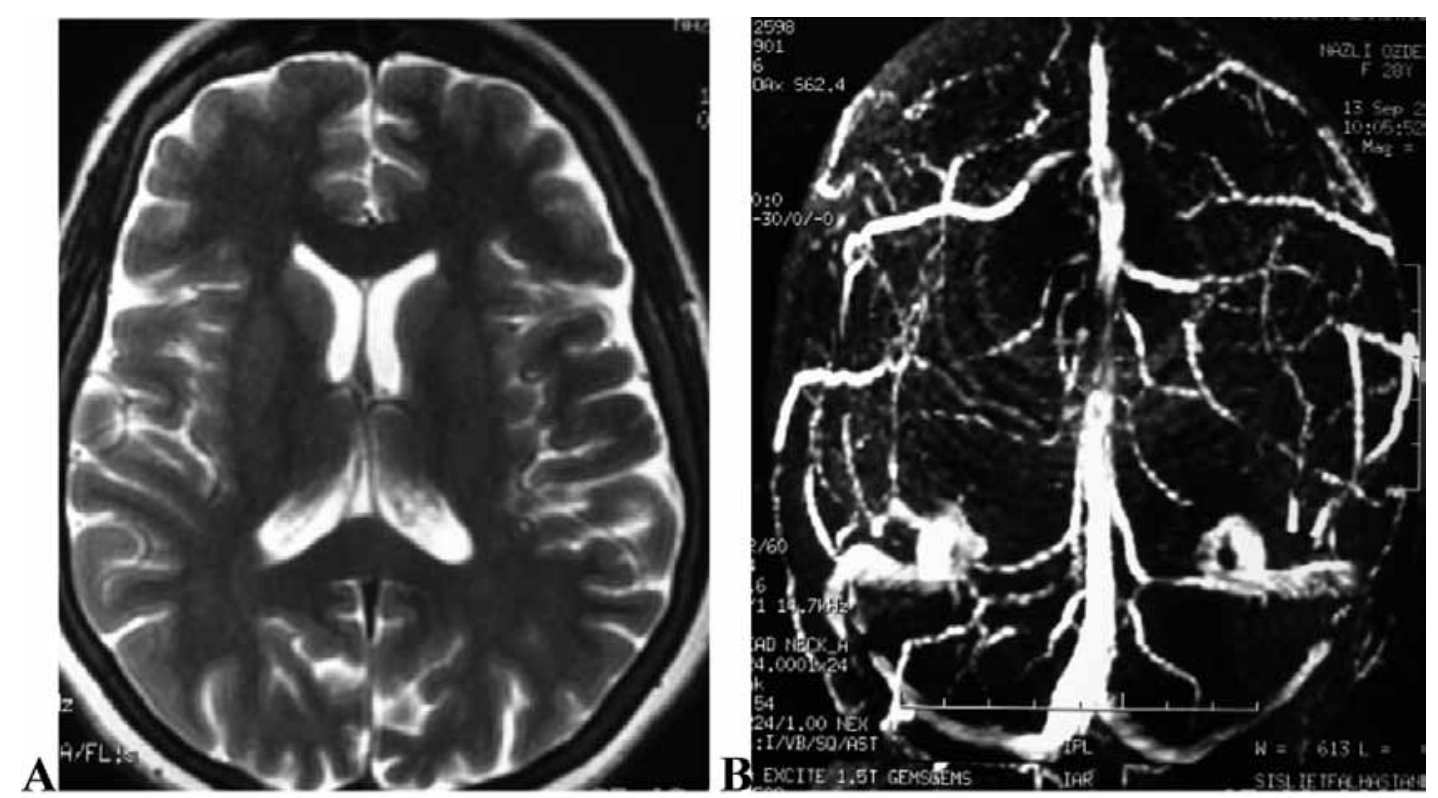

Şekil 2: Kranial MR T2 ağırlıklı inceleme (A) ve kranial MR venografi (B) normal olarak izleniyor

hipertansiyon ise dört hastada saptanmıştır. Bu hastaların tedavisinde tekrarlayan boşaltıcı lomber ponksiyonlar, 4 hastada IV metilprednizolon ve tümünde cerrahi uygulamalar yapılmış ve esas olarak erken cerrahinin faydalarına dikkat çekilmiştir.

Bizim hastamızda görme kaybını hızlandırmış olabilecek demir eksikliği anemisine dikkat çekmek uygun olur. Hızlı ilerleyen ve totale yakın görme kaybı olan hastamızda asetolazamid oral tedavi olarak kullanıldı. Tekrarlayan lomber ponksiyonlar yapıldı

\section{KAYNAKLAR}

1. Behrens MM, Odel JG. Impared vision;symptoms of neurological disorders. In Rowland LP (editor).Merrit's Neurology. $11^{\text {th }}$ Edition, Philadelphia: Lippincott Williams \& Wilkins, 2005.

2. Friedman DI, Jacobson DM. Diagnostic criteria for idiopatic intracranial hypertension. Neurology 2002;59(10):1492-95.

3. Thambisetty $M$, Lavin PJ, Newman NJ, Biousse V. Fulminant idiopatic intracranial hypertension; Neurology 2007;68(3):22932. ve IV metilprednizolon tedavisine de iyi cevap alındı. Birinci haftanın sonunda lumboperitoneal şant işlemi yapıldı ve görmedeki düzelme belirginleşti.

Sonuç olarak akut intrakraniyal basınç artışı ile gelen ve hızlı ilerleyen görme kaybı olan bu hastalarda cerrahinin yapılabilen en erken dönemde yapılması esastır. Bunun dışında zaman kazandırıcı olarak boşaltıcı lomber ponksiyonlar ve özellikle kısa süreli IV kortikosteroid kullanımına dikkat çekmek gerekir.

4. Mathews MK, Sergott RC, Peter J. Pseudotumor cerebri. Savino. Curr Opin Ophthalmol 2003; 14(6): 364-370.

5. Celebisoy N, Gökçay F, Sirin H, Akyürekli O. Treatment of idiopathic intracranial hypertension: topiramate vs acetazolamide, an open-label study. Acta Neurol Scand. 2007;116(5):322-7. 